cathedral city of St. Asaph, are situated the Cefn Caves. It had been rumoured of late that parties visiting this place had on several occasions seen some strange animal creeping in its dark recesses, and on Saturday visitors reported having had a good view of h:m, and stated it was a huge beast of the lizard tribe. On the Monday following Thomas Hughes, from Rhyl, went to try to capture him. Armed with a stout stick he approached its reworted lair, but not seeing it he decided to remain in ambush at the mouth of the cave, sheitered by a projecting ledge. After jiaving thus waited an hour his patience was rewarded with success. He could hear in the far end a hum as of a hive of bees. The sound growing louder, and now apparently quite close, Hughes peeped round the ledge, and saw the monster within three yards of him. He (Hughes) sprang towards him, and dexterously wielding his stick he dealt him a well-aimed blow upon the neck just behind the head, which caused him to stagger and reel. One more blow in the abdomen finished hin. Hughes carried him home in triumph, and is now making a profit out of the affair by exhibiting him at Rhyl. The monster is of the lizard tribe, as mentioned above. Only that our country is destitute of those creatures we should have said it was a young crocodile. It measures from the nose to the end of its tail exactly $4 \mathrm{ft}$. 7 in., the tail being rather more than half that length. Its limbs measure r2in.; the front ones have five toes; and the hind ones four; it is webfooted. Above it is black and white beneath. Its coat is mailed, quite hard, and protruding in sharp corners and angles, like the crocodile's. The head is low and flat, the mouth large and round at the end, measuring 7in. by 3in.; the teeth are numerous, but small, and bear great resemblance to those of a large codfish. There is ample scope here for natuialists to investigate the how and wherefore this strange amphibian came to be discovered in the present epoch among the hills of North. Wales."

Such is the vivid account of the capture given in the Times, and reprinted in several local papers; and so far as I can judge by my letters, believed in by many simple-minded people. It is altogether a most impudent hoax. The man Hughes is a sweep, who purchased a reptile which happened to die in a travelling menagerie at $\$$ t. Asaph, and exhibited it at Rhyl as having been caught in the Cefn Caves, until at last it became a public nuisance, and was committed to the earth. The story related in the Timzes was invented merely to make the exhibition lacrative to Hughes the sweep. Its wide circulation, which incidentally shows an astonishing ignorance of natural history, is the ouly excuse for my writing this letter.

\section{MAN AND NATURAL SELECTION}

$r \mathrm{HE}$ following reply to $\mathrm{M}$. Claparède's "Remarques à propos de l'ouvrage de M. Alfred Russel Wallace sur la Théorie de la Sélection Naturelle," was written some months ago, and was intended as an appendix to a French translation of my "Essays" by M. Lucien De Candolle, to be published by Reinwald, of Paris. As it is now very uncertain when the translation will appear, and as $M$. Claparède's critique has been highly spoken of in several English periodicals, I think it advisable that my answer to it should be no longer delayed.

In the "Archives des Sciences de la Bibliothèque Universelle," for June, I 870, M. Edouard Claparède has done me the honour to make my "Contributions to the Theory of Natural Selection" the subject of some critical remarks. To these I now propose briefly to reply.

I must premise that $I$ do not intend to discuss here any of those difficulties which my critic finds in the theory of sexual selection, and which apply as much to Mr. Darwin's views as to my own, because, in his new work now announced, that theory will, I have no doubt, be fully developed, and be supported by a mass of facts and observations, in the absence of which further argament is useless. I proceed therefore to the objections that apply more especially to my own views.

At p. 15 of his "Remarques" M. Claparède says, "Son étude est consacrée á la coloration des oiseaux et, absorbé dans son sujet, l'auteur oublie que d'autres facteurs peuvent, aussi bien que la couleur, attirer l'attention des ennemis sur la gent ailée. Un nid couvert d'un dôme volumineux échappera tout aussi peu, grâce à ses dimensions, à l'œil d'un animal en quête de proie, que quelques plumes brillainent colorées. Les gamins de nos villages en savent quelque chose, comme l'a remarqué $\mathrm{M}$. le Duc d'Argyil, et ils ne réussissent que trop, à la présence d'un gros nid, à deviner l'oiseau caché et sa couvée." This objection does not seem to me very serious, because in the first place, nests, however large, generally harmonise in colour with surrounding objects, and are not so easily seen at a little distance as a bright patch of colour; and, secondly, because "gamins" are not the chief natural enemies of the feathered tribes, while hawks and falcons do not break open nests, although they do seize and devour birds.

After giving (p. 23-25) what I must allow to be a very fair abstract of my reasons for believing that Natural Selection is not the only power that has operated in the development of man, $\mathrm{M}$. Claparède intimates that I have so completely abandoned my own Darwinist principles that the reader will easily refute my arguments. $\mathrm{He}$ therefore confines himself to certain "reflections." I regret that he did not think it necessary to do more than this, because I have as yet in vain sought from my reviewers for any other than general objections to my arguments on this subject, and am at a loss to know how they can be so easily refuted. M. Claparède's "Reflections," however, do, fortunately, take the form of arguments. He says (p. 25), "M. Wallace n'a pas reculé devant l'explication de la formation graduelle du chant de la fauvette et du rossignol par voie de selection naturelle. La chose est toute simple, bien fou serait celui qui voudrait recourir ici à l'intervention d'une Force supérieure, ami dtr Beau! Les fauvettes femelles et les rossignols de même sexe ont toujours accordé de prêfêr. ence leur faveurs aux mâles bons chanteurs. C'était la conséquence de leur goûts musicaux et des aptitudes harmoniques de leur oreille. Malheur aux pauvres mâles à registre peu étendu ou à timbre fêlé ! les douceurs de la paternité leur ont été impitoyablement refusées; ils sont morts de jalousie dans la tristesse et l'isolement. Ainsi s'ést formée la race des bons chanteurs qui peuplent nos bocages. Pourquoi n'y a-t-il pas des chanteuses? Sans doute que les oiseaux mâles ne se sont jamais souciés de la voix de leurs épouses, soit parcequ'ils n'avaient pas l'oreille juste, soit plûtot, car cela sera contradictoire, parceque leurs gouts musicaux étaient suffisament satisfaits par leurs concerts personels. Peut-être aussi les femelles n'avaient-elles point d'aptitude virtuelle au perfectionnement de la voix; peut-être avaientelles atteint l'extrême limite de développement vocal compatible avec l'organisation d'un oiseau du sexe féminin; ou bien enfin la sélection naturelle produite sous l'influence des poursuites exercées par des ennemis de toutes sortes contre les belles couveuses, sélection favorable, selon $M$. Wallace, à la production de couleurs sombres, a-t-elle mystérieusement éteint même l'éclat de sa voix? Quoiqu'il en soit, il est évident pour M. WaJlace que la sélection sexuelle, en d'autres termes le goût des dames fauvettes pour la musique, a amené le grand perfectionnement de la voix des virtuoses de l'autre sexe. Mais dans l'espèce humaine, la chose aurait-elle pu se passer ainsi? Le chant harmonieux et enchanteur d'une prima donna aurait-il pu naître et se perfectionner par voie de sélection? Le goût musicale des auditeurs pourrait-il avoir eu une influence selectrice sur ce phénomène? Jamais, au grand jamais! Seule l'inter. vention d'une Force supérieure a pu amener un résultat pareil, car jamais homme primitif n'a eu de goût pour la musique. M. Wallace le sait bien: il a vécu si longtemps parmi les sauvages qui ont pu le lui dire! Au contraire, les femelles fauvettes primitives et les femelles rossignols primitives, avaient déjà le goût musical longtemps avant que leurs époux eissent appris à chanter. 
Comment M. Wallace le sait-il? Le lui ont-elles dit? N'importe, il le sait."

It is a pleasure to read anything so brilliant as this, but it hardly seems to touch the point of my argument. Male birds do sing at pairing time to the females. Mr. Darwin says in his "Origin of Species," "All those who have attended to the subject believe that there is the severest rivalry between the males of many species to attract, by singing, the females." Female birds do not sing. These are facts, and they perfectly accord with the theory of the perfection of song having been developed, in the males, by sexual selection. In man the facts are all different. Savage women have generally no choice as to their husbands, as has been so fully shown by Sir John Lubbock; and in the few cases where a choice is open to them, there is not a particle of evidence to show that a musical voice ever determines that choice. Still less reason is there to think that this quality determines the male savage in choosing his wife. Yet a wonderful musical organ has been developed in both sexes, of which the use to man in his struggle for existence has not yet been shown. Surely here is a difficulty which required facts and arguments for its elucidation rather than a brilliant display of wit.

Again, in reply to my arguments as to the total absence of hair from the back of man, we are told that it should be no difficulty to a person who believes that hairy mammals and feathery birds have been derived from scaly reptiles ("Remarques," pp. 27,28). But surely this is not the argument of a Darwinian. For the hair and the feathers are useful to their several possessors, just as the scales were to their ancestral reptiles; whereas the very essence of my difficulty is, that the nudity has not been shown to be ziseful to man. M. Claparède thus concludes his remarks on this subject:- "Que M. Wallace soit att moins conséquent dans la question de la chute des poils. Si l'interveniton d'une Force supérieure lui semble nécessaire pour épiler le dos de l'homme, qu'il sache se résoudre à la faire agir de même sur l'échine de l'éléphant, du rhinocéros, de i'hippopotame ou du cachalot." But the four mammals here mentioned are thick-skinned animals, one aguatic, one amphibious, the other two inhabitants of hot countries, lovers of shade and of marshes. Can anything be more clear than that, in all these cases, the hair was little or not at all wanted, and, owing to their habits, was very probably even injurious, and has therefore partially disappeared by means of natural selection? while the extinct mammoth and woolly rhinoceros are instances which prove that it always re-appeared when the needs of the animal required it. If the hair disappeared from the back of tropical man by the action of the same law which caused it partially to disappear from the tropical elephant, we must ask why it did not re-appear in the arctic Finns and Esquimaux, as it re-appeared in the arctic mammoth? It is rather for me to say - "Que M. Claparède soit au moins conséquent dans la question de la chute des poils."

The last point on which my critic remarks is my argument, that the brain of savage man is in advance of his needs, and therefore could not have been acquired by natural selection; and he asks, why I do not apply the same reasoning to many other cases, especially to that of the great group of birds with a complex larynx, comprising all the singing birds, yet having many species which do not sing. He says (p. 29), "Ces oiseaux possedent dans leur larynx un organe beaucoup trop bien conformé pour l'usage qu'ils en font. Il est donc nécessaire d'admettre l'intervention d'une Force supérieure pour façonner cet appareil, inutile aux oiseaux qui le possèdent, mais calculé en vue de générations nouvelles qui, dans un avenir plus ou moins éloigné et dans des conditions déterminées apprendront à chanter. Que M. Wallace aurait-il à répondre aे une semblable argumentation ?" My answer is, that the cases are not parallel or similar; if they were so, I should certainly adopt the same conclusion in both. To make them logically comparable, it would be necessary to prove that all the earlier forms of the group had the vocal organs fulky developed, but did not sing; or what might be held to indicate this, that at present only a few species sing, while the great mass do not. But so far from this being the case, the majority of the species of the group have musical or sonorous voices, and there is no evidence to show that the vocal apparatus was fully developed before the power of singing began to be exercised. Man, on the contrary, stands alone in the development of his brain, and $M$. Claparede does not rebut the evidence I have adduced to show that the brain in savage and prehistoric man was in advance of his requirements.

In concluding his remarks, $M$. Claparède endeavours to impale me neatly on the horns of a dilemma, as follows:"Ou bien M. Wallace a eu raison de faire intervenir une Force supérieure pour expliquer la formation des races humaines et guider lhomme dans la voie de la civilisation, et alors il a eu tort de ne pas faire agir cette même force pour produire toutes les autres races et espèces animales ou végétales; ou bien il a eu raison d'expliquer la formation des espèces végétales et animales par la seule voie de la sélection naturelle, et alors il a eu tort de recourir à l'intervention d'une Force supérieure pour rendre compte de la formation des races humaines." These are his last words, and they seem to me to be the weakest in the whole paper, being a pure begging of the question. They assume that man presents no phenomena which differ in kind from those presented by other animals, whereas I have adduced a number of such phenomena which my critic has. neither disproved nor denied. My whole argument is founded on certain facts, and on these facts only. My critic admits the facts, does not refute my arguments, set maintains that I should give up my conclusion, because the theory of Natural Selection must apply equally to man and the rest of Nature, or to neither. But why must it do so? Darwin himself claims no such universality for it. $\mathrm{He}$ admits that even the common origin of animals and plants rests only on analogy, and that "it is immaterial whether it is accepted or not." But $M$. Claparède is more Darwinian than Darwin himself, and would, I presume, say that, either all animals or plants must be descended from one common ancestor or, that no two species are thus descended. I maintain, however, that man is descended from a lower animal form, but I adduce facts which go to prove that some other law or power than Natural Selection has specially modified him. If Darwin is not anti-Darwinian in admitting, as he does, the possibility that animals and plants may not have had a common ancestor, I may surely deny that I am anti-Darwinian when I show that there are certain plenomena in the case of man that cannot be wholly explained by the law of Natural Selection.

I must not conclude without thanking M. Claparède for the very flattering terms in which he has spoken of the larger portion of my work, and also for the general accuracy and fairness with which he has condensed my views and arguments in the last essay, to which he especially takes objection.

A. R. WAJLACE

\section{THE NATURAL HISTORY UF MAN*}

$\mathrm{I}$ the two handsome volumes before us is contained such a mass of interesting information concerning our less cultivated brethren as has surely never yet been collected by one writer or in one work. The first volume is occupied with Africa, that vast, and, as recent researches show, densely populated land, whose peoples present a greater variety of manners and customs and languages than any others upon the globe, and the second treats of

* "The Natural History of Man; being an Account of the Manners and Customs of the Uncivilised Races of Men." By the Rev. J. G. Wood, M.A., F.L.S., with new designs by "Zwecker, Angas, Danby, Handley, \&.c. Engraved by the Brothers Dalziel. 2 vols. $1868-70$. (London: Gerrge Routledge and Sons.) 